\title{
Plant composition and structure of two post-livestock areas of Tamaulipan thornscrub, Mexico
}

\author{
Miguel A. Pequeño-Ledezma ${ }^{1}$, Eduardo Alanís-Rodríguez² ${ }^{2}$ Víctor M. Molina-Guerra ${ }^{3}$, Arturo Mora-Olivo ${ }^{4 *}$ (D, \\ Alejandro G. Alcalá-Rojas ${ }^{5}$, José Guadalupe Martínez-Ávalos ${ }^{4}$ and Fortunato Garza-Ocañas ${ }^{2}$
}

\begin{abstract}
Background: The composition, structure and biological diversity of two regenerated areas after livestock activities in a Tamaulipan thornscrub vegetation from Northeast Mexico were evaluated. The regeneration of each area was evaluated with the establishment of 12 sampling sites of $50 \mathrm{~m}^{2}$. From the data obtained ecological indexes such as: Importance Value Index and Diversity (alpha and beta) were evaluated.

Results: A total of 17 families, 40 genera and 42 species were registered, the most representative family was Fabaceae with 11 spp. The intensive livestock area had 36 species; a Margalef index of 4.44 and a 1.24 Shannon index, while the extensive livestock area had 32 species, a Margalef index of 4.24 and a 2.16 Shannon index. The communities evaluated have a (48\%) mean similarity.

Conclusions: 1) Regenerated communities after livestock use showed higher richness of species and alpha diversity. 2) Evaluated communities have a mean similarity of (48\%). 3) Even after 25 years of regeneration the most dominant species was Cenchrus ciliaris that is used for cattle forage.
\end{abstract}

Keywords: Diversity, Livestock, Mexican scrubs, Plant regeneration, Shannon index

\section{Background}

Livestock activity represents $5 \%$ of the global gross domestic product (GDP), almost $29 \%$ of the terrestrial surface corresponds to permanent grasslands or to systems of forage cultivation used for feeding cattle [1]. In México livestock activity stands for $56 \%$ of the national territory and some northern states are used for this particular purpose [2]. The state of Nuevo León has a livestock area of $86 \%$ from its total surface (i.e. 5.5 million of hectares), from these $90 \%$ are used for livestock and $10 \%$ are used for cultivating grasslands with different species [2]. However, it is evident that in conjunction with other human activities, livestock farming has strongly influenced some natural ecosystems in this state and in other regions of the country [3].

In general, the current demand for cattle has led to changes on the traditional extensive production form (large

\footnotetext{
* Correspondence: amorao@uat.edu.mx

${ }^{4}$ Instituto de Ecología Aplicada, Universidad Autónoma de Tamaulipas,

División del Golfo 356, 87019 Ciudad Victoria, Tamaulipas, Mexico

Full list of author information is available at the end of the article
}

areas with natural vegetation) to a gradual shifting to an intensive form (small areas in where natural vegetation is replaced by grassland). The change is causing severe damage to natural plant communities, especially those in arid and semi-arid areas as scrubs [4]. In fact, thornscubs are the most extensive and historically, the most widely used vegetation type in the arid and semiarid zones of Mexico [5, 6]. This vegetation type has been affected by antropogenic activities for different uses and purposes [5, 7]. In the same way, it has suffered continuous deforestation and land use changes due to introduction of livestock $[3,8,9]$.

In the 1960 and 1980's 3 million hectares were deforested to produce buffel grass (Cenchrus ciliaris L.) in the states of Coahuila, Nuevo León and Tamaulipas and by 1998 only 1 million hectares remained [10]. Thus, livestock areas are usually used only for some time and abandoned when their productivity is lower. These areas do regenerate naturally but there is scarce information and knowledge about the resulting vegetation commu-

(c) The Author(s). 2018 Open Access This article is distributed under the terms of the Creative Commons Attribution 4.0 International License (http://creativecommons.org/licenses/by/4.0/), which permits unrestricted use, distribution, and reproduction in any medium, provided you give appropriate credit to the original author(s) and the source, provide a link to the Creative Commons license, and indicate if changes were made. The Creative Commons Public Domain Dedication waiver (http://creativecommons.org/publicdomain/zero/1.0/) applies to the data made available in this article, unless otherwise stated. 
nities $[8,11]$. Results of previous investigations indicated that the arboreal and shrub plant community of Tamaulipan thorny scrub regenerates after it has been abandoned and the intensity and time of the activity influences the final result of plant composition after regeneration [12, 13]. Due to the intense land use change and the scarce researches done in this ecosystem, it is important to develop studies of vegetation communities after disturbance due to different management practices, in order to provide documentary bases to establish the direction of successional development in different vegetation communities [14, 15].

This study has the main objective of evaluate regenerated vegetation communities after livestock activity intensities (i.e. intensive and extensive livestock), at the Tamauilipan thornscurb of Northeastern México. From the evaluation we obtained ecological indicators such as 1) abundance, dominance (canopy area), frequency and the importance value index, 2) alpha diversity (specific richness, Margalef and Shannon Indexes), 3) beta diversity. The hypothesis of this study is that the area used with intensive livestock will have lower values of coverage, density and species richness.

\section{Methods}

\section{Study area}

This study was carried out in a Tamaulipan thornscrub vegetation regenerated after livestock activities in Northeastern Mexico in the municipality of Pesquería, Nuevo León
(Fig. 1). This area is located at an altitude of $310 \mathrm{~m}$. The climate in the area is considered as dry BSOhw according to Köppen as modified by García [16] for the Mexican Republic. The mean annual temperature is $20^{\circ}$ a $22^{\circ} \mathrm{C}$ and the hottest months are July and August whereas the lower temperatures occur in December and January with $13{ }^{\circ} \mathrm{C}$ a $14{ }^{\circ} \mathrm{C}$.

Some of the species with the highest importance value index in the region are Leucophyllum frutescens (Cenizo), Cordia boissieri (Anacahuita) y Acacia amentácea (Gavia), Prosopis glandulosa (Mezquite), Havardia pallens (Tenaza), Acacia farnesiana (Huizache), Parkinsonia texana (Palo verde) and Celtis pallida (Granjeno) [6].

\section{Floristic inventory}

In order to accomplish the main objective of this study, two vegetation communities with different historical livestock uses were selected. The extensive livestock area $\left(25^{\circ}\right.$ $43^{\prime} 25.46^{\prime \prime}, 99^{\circ} 58^{\prime} 7.15^{\prime \prime}$ and $18.58 \mathrm{ha}$ ), was influenced by decades of use with selective extraction of woody species as well as for tramping and feeding activities of livestock.

In 1998 productive activities in this area were abandoned. In the area with a historical intensive livestock activity $\left(25^{\circ}\right.$ $43^{\prime 2} 25.63^{\prime \prime}, 99^{\circ} 58^{\prime} 19.43^{\prime \prime}$ and $28.66 \mathrm{ha}$ ), the secondary vegetation was eliminated and in 1977 an exotic grassland (Cenchrus ciliaris) was established and livestock were grassing there for 10 years (i.e. 1978-1988). In both areas, productive activities were abandoned and regeneration occurred naturally.

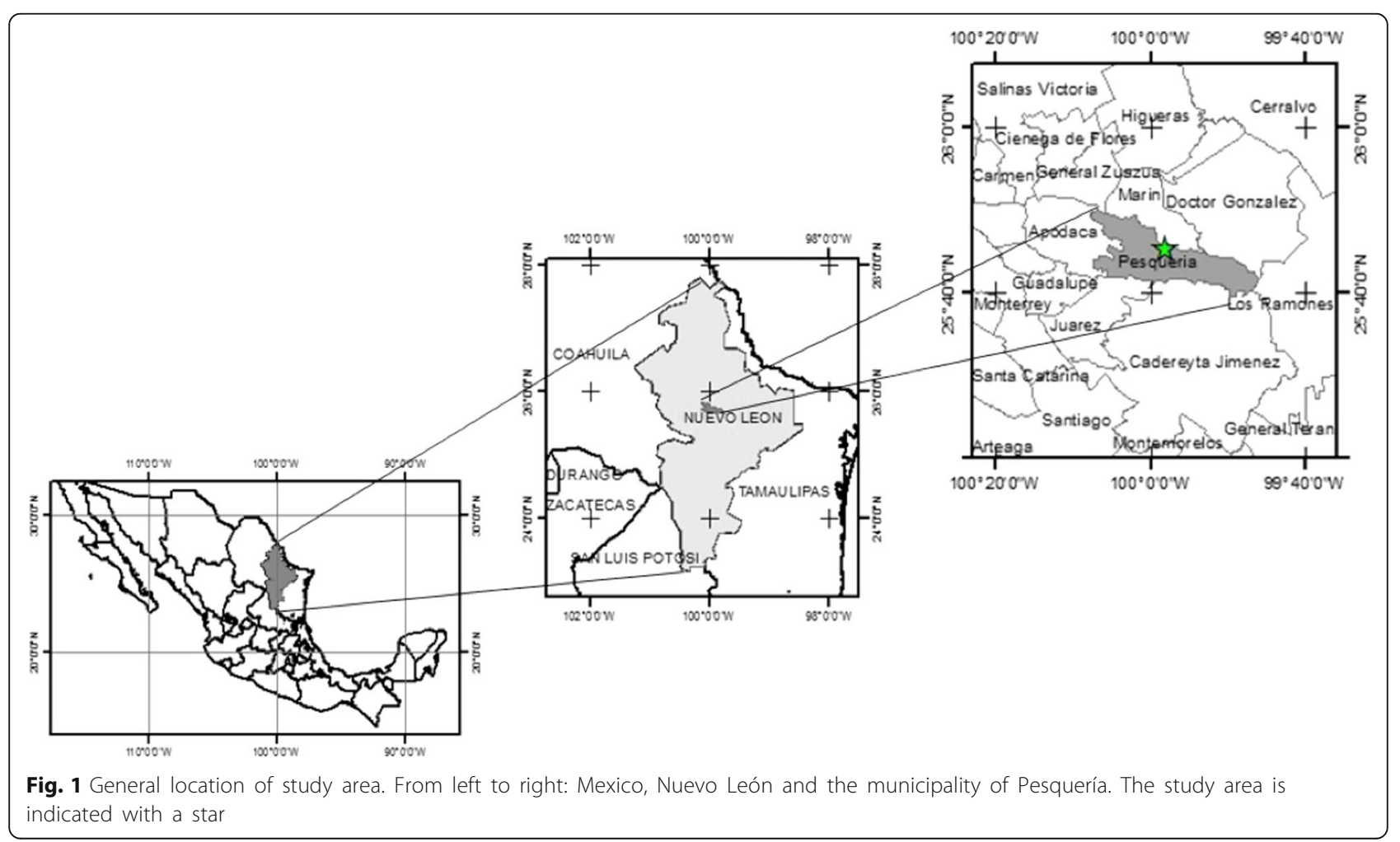


After twenty five years livestock activities (i.e. in 2013), the vegetation communities were evaluated in both areas. In order to evaluate regeneration 12 sampling sites (i.e. 24 in total) in each area were established. Rectangular sampling sites of $50 \mathrm{~m}^{2}(5 \times 10 \mathrm{~m})$ were used for facilitating the limits and measurements in dense vegetation when compared with circular shaped sites [17].

Distribution of sampling sites was randomly selected and information of all trees, shrubs and herbaceous species was registered. Trees and shrubs with a basal diameter of $d_{0.10}>1 \mathrm{~cm}$, were evaluated as well as all herbaceous species.

\section{Data analysis}

Abundance was determined for each species, considering the number of individuals, their dominance regarding the function of the canopy coverage and its frequency based on its existence in sampling sites. Results were used in order to obtain a balance value at the taxon level named Importance Value Index (IVI), which has percentage values in a scale of 0-100 [18]. For relative abundance estimate the following equation was used:

$$
A R_{i}=\left(A^{A} / \sum_{i=1 \ldots n} A_{i}\right) \times 100 \quad A_{i}=N_{i} / S
$$

Where $A_{i}=$ absolute abundance, $A R_{i}=$ relative abundance of the species i respect to the total abundance, $\mathrm{N}_{\mathrm{i}}$ $=$ number of individuals of the species $\mathrm{i}, \mathrm{S}=$ sampling surface (ha). Relative dominance was evaluated by means of:

$$
D R_{i}=\left(D^{D_{i}} / \sum_{i=1 \ldots n} D_{i}\right) \times 100 \quad D_{i}=A b_{i} / S(h a)
$$

Where $D_{i}=$ absolute dominance, $D_{i}=$ relative dominance of the species $i$ respect to the total dominance, $A b_{i}=$ canopy area for the species $i$ and $S=$ surface (ha). Relative frequency was obtained with the following equation:

$$
F R_{i}=\left(F_{i} / \sum_{i=1 \ldots n} F_{i}\right) \times 100 \quad F_{i}=P_{i} / N S
$$

Where $F_{i}=$ absolute frequency, $F_{i}=$ relative frequency of the species $i$ with respect to the total frequency, $P_{i}=$ number of site per species occurrence $i$, NS the total sampling sites number. The importance value index (IVI) has percentage values from 0 to $100 \%$ and is taken in accordance to $[19,20]$ :

$$
I V I=\frac{A R_{i}+D R_{i}+F R_{i}}{3}
$$

Where $A R_{i}=$ Relative abundance of the species $i$ with respect to total abundance, $\mathrm{DR}_{\mathrm{i}}=$ relative abundance of the species $\mathrm{i}$ respect ot total dominance, $\mathrm{FR}_{\mathrm{i}}=$ relative frequency of the species i respect to total frequency.

In order to determine alfa diversity two indexes were used, Margalef $\left(\mathrm{D}_{\mathrm{Mg}}\right)$ [21] corresponding to the number of present species (richness of species) and that by Shannon $\left(\mathrm{H}^{\prime}\right)$ [22] corresponding to the community structure, i.e. the proportional distribution of the value given to each species. The following formulas were used for its calculation:

$$
\begin{aligned}
D_{M g} & =\frac{(S-1)}{\ln (N)} \\
H^{\prime} & =-\sum_{i=1}^{S} p_{i} \times \ln \left(p_{i}\right) \\
p_{i} & ={ }^{n} / N
\end{aligned}
$$

Where $\mathrm{S}=$ number of present species, $\mathrm{N}=$ number of total individuals, $n_{i}=$ number of individuals per species $\mathrm{i}$, $\mathrm{p}_{\mathrm{i}}=$ proportion of individuals of species $i$ with respect to the total number of individuals.

In order to determine variability of species composition between the sampling units, the beta diversity was used. Similarity of vegetation communities was calculated using the Sorensen similarity coefficient used for quantitative data $\left(\mathrm{I}_{\text {Scuant }}\right)$ using the formula by Magurran [23]:

$$
I_{\text {Scuant }}=\frac{2 p N}{a N+b N}
$$

Where $\mathrm{aN}=$ total number of individuals in the site $\mathrm{A}$, $\mathrm{bN}=$ total number of individuals in the site $\mathrm{B}, \mathrm{pN}=$ Summary of the lower abundance of the shared species between both sites.

In order to determine differences between density and canopy, as well as between the Margalef and Shannon indexes of both thornscrub areas, the mean values from the sampling sites were added. When data was arranged with the normality and homogenicity criteria a $\mathrm{T}$ test with a $(\alpha=0.05)$ was carried out.

\section{Results}

Forty two species from 40 genera and 17 families were registered (Additional file 1). The most representative families were Fabaceae with 11 species (26.19\%), Asteraceae with 6 especies. (14.28\%) and Euphorbiaceae, Poaceae and Rhamnaceae with 3 species each (7.14\%). These families had 24 genera and 26 species, corresponding to $62 \%$ of the registered flora in the study area. In the study area species with higher abundance, frequency and dominance values were: Cenchrus ciliaris, Parkinsonia texana and Cordia boissieri. Cenchrus ciliaris had the higher ecological importance for the community (Table 1). 


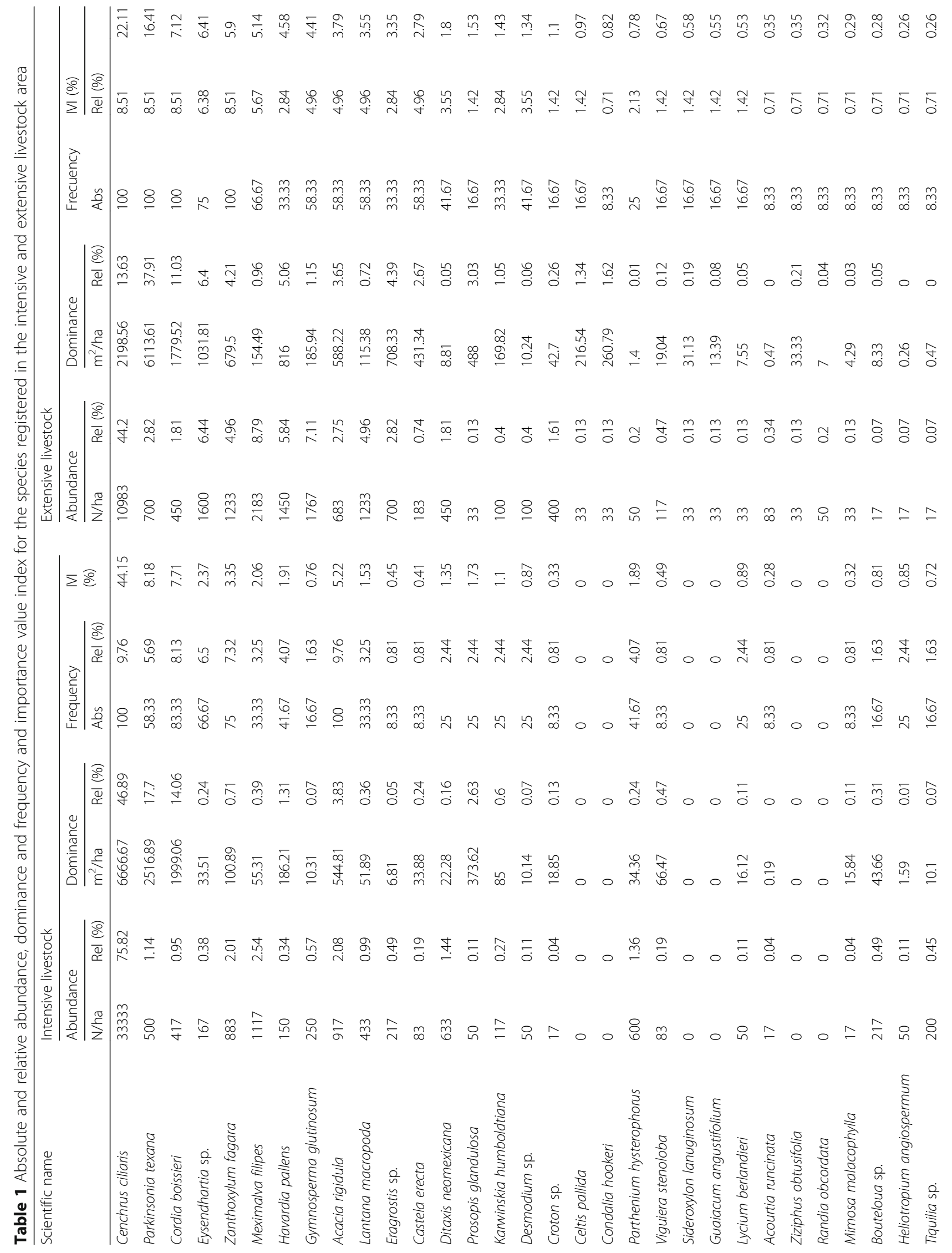




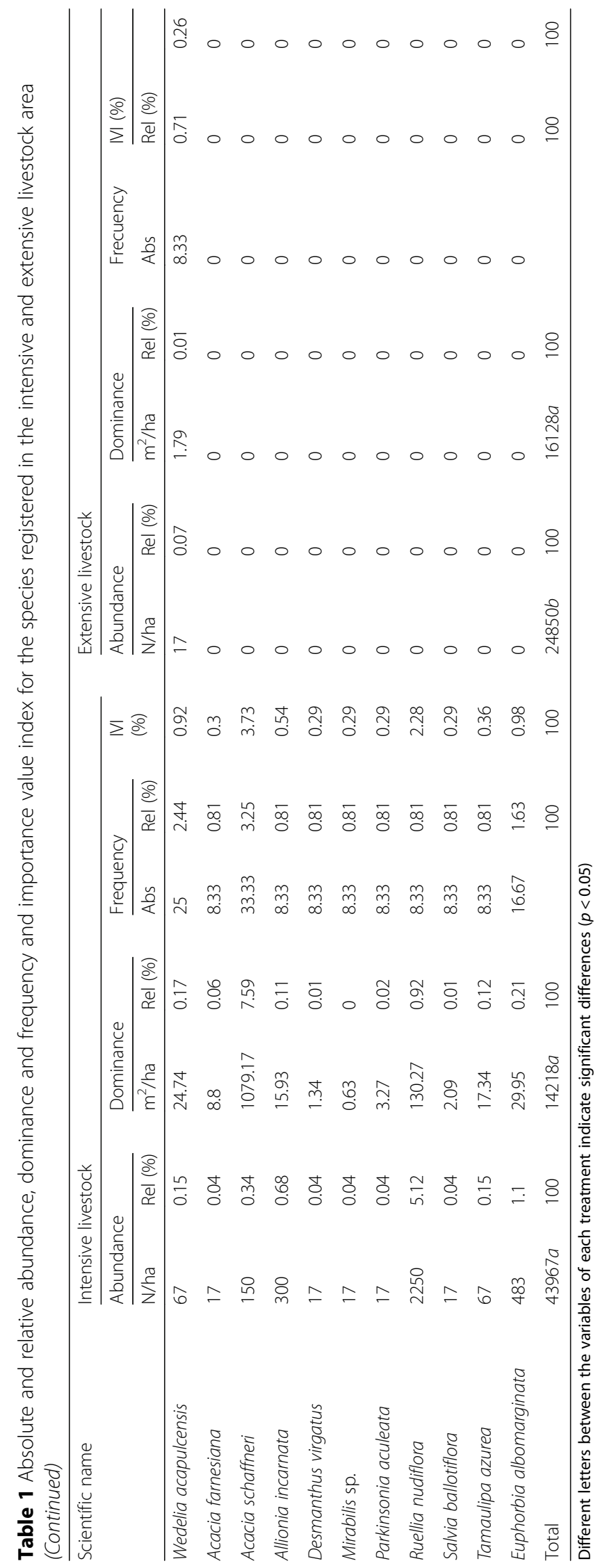


The area with intensive livestock history had a density of 43,967 N/ha, and Cenchrus ciliaris represents $75 \%$. This vegetation community has a canopy coverage higher than $100 \%$ and overlapping of canopies. The species that showed a higher canopy coverage were: Cenchrus ciliaris (46.89\%), Parkinsonia texana (17.70\%) and Cordia boissieri (14.06\%), adding up to $79.19 \%$ of the coverage. The species with the higher ecological importance in this community were Cenchrus ciliaris (44.15\%), Parkinsonia texana (8.18\%) Cordia boissieri (7.71\%), Acacia rigidula (5.22\%), and Acacia schaffneri (3.73\%).

The area with the historical extensive livestock activity has a density of 24,850 N/ha, and Cenchrus ciliaris represents $44 \%$. This vegetation community has a canopy coverage of $16,128 \mathrm{~m}^{2}$. The species that showed a higher canopy coverage were Parkinsonia texana (37.91\%) Cenchrus ciliaris (13.63\%) and Cordia boissieri (11.03\%) adding to $62.57 \%$ of the total coverage.

The species with the higher ecological importance in the study area were: Cenchrus ciliaris (22.11\%), Parkinsonia texana (16.41\%), Cordia boissieri (7.12\%), Eysendhartia sp. (6.41\%), and Zanthoxyllum fagara (5.9\%).

Density for individuals was statistically different between thornscrubs $(P<0.000)$, while plant cover showed similarity $(P=0.081)$.

\section{Diversity}

According to the alpha diversity, the vegetation community with intensive livestock history showed a richness of species of 36 and extensive livestock had 32. Margalef index (specific richness) showed values of $\mathrm{DMg}=4.44$ and $\mathrm{D}_{\mathrm{Mg}}=4.24$ respectively. Margalef index values between thornscrubs showed a statistical similarity of $(P<0.000)$.

In relation to the Shannon index, the area with the intensive livestock history had a value of $\mathrm{H}^{\prime}=1.24$ and the extensive livestock area had $H^{\prime}=2.16$. These values showed a statistical difference of $(P=0.097)$.

\section{Discussion}

Forty two species, 40 genera and 17 families (see Table 1) were registered. The most representative family was Fabaceae with 11 species (26.19\%). The high presence of this family, and of the Acacia spp., could represent an important input of nitrogen to the ecosystem due to its capacity to fix atmospheric $\mathrm{N}_{2}[24,25]$. The abandoned areas that have been stripped of their natural vegetation coverage and used for agricultural and livestock practices tend to have a low availability of nitrogen in soil, when compared with undisturbed areas subjected to secondary succession [26], so that species fixing atmospheric nitrogen have some advantage on others, specially in the early stages of secondary succession $[5,27]$. These results are in accordance with those reported by several authors $[14,28,29]$, they obtained similar numbers of families, genera and species, and they also found the Fabaceae family as the most representative of different regenerated areas. The greater amount of legumes can also be explained by their tolerance to edaphic drought conditions of the study area, since these species have higher values in water potential of the xylem at pre-dawn and at noon, under drought conditions, compared to other species $[29,30]$. Apparently the abundance of species of this family represents a clear example of over grassing activities according to Palacios [31].

Cenchrus ciliaris was the most valuable species in both areas. This might be because it is an invasive not native species that adapts well to arid and semi-arid ecosystems [32]. Some of its characteristics are the accumulation of carbohydrates at the base of their stems for slow release when necessary, a system of deep roots (up to $2.5 \mathrm{~m}$ in deep soils), as well as the extended longevity of seeds and opportunistic germination [33,34]. The richness of species values and Margalef index registered in historical intensive livestock activities are high when compared with post livestock regenerated areas [11], where the community has values of $\mathrm{D}_{\mathrm{Mg}}=1.40$. Jimenez et al., [35] evaluated the species regeneration diversity for woody species at the Tamaulipan thornscrub with agricultural history in Northeastern Mexico reporting values of $\mathrm{D}_{\mathrm{Mg}}=2.17$. These values are high when compared to those reported by Mora-Donjuan et al., [36] who evaluated diversity and composition in a microphil desert thorscrub with livestock history in northeastern Mexico and registered values of $\mathrm{D}_{\mathrm{Mg}}=2.29$.

Respect to the Shannon index, the intensive livestock area values obtained are low whereas in the extensive livestock area values are similar when compared to those registered by Molina-Guerra et al., [37], they reported composition and diversity of two areas with livestock grassing systems at the Tamaulipan thornscrub in Northeaestern Mexico and obtained values for Shannon $H^{\prime}=>2.22$ and 2.11. Jimenez et al., [12, 28] evaluated regenerated areas with different productive usage history and recorded values that were slightly lower for alfa diversity $H^{\prime}=1.11$ when evaluating the regeneration of woody species at the Tamaulipan thornscrub with intensive livestock history compared with results showed in the study $\left(H^{\prime}=1.24\right)$.

Values registered in this study are slightly lower when compared with those reported by Canizales et al., [38], they made an structural characterization of the submontane thornscrubs at the Sierra Madre Oriental and had values of $H^{\prime}=3.0$. According to the beta diversity, vegetation communities have a similarity of 0.48 for the species representing $48 \%$ of similarity. This dissimilarity of (52\%) in the study areas is related to the fact that the intensive livestock area has 10 species that are exclusive, and not shared with the extensive livestock area, which has only 5 
exclusive species. These results are similar to those reported by Alanís et al. [8], they evaluated regenerated areas of the Tamaulipan thornscrub and mentioned that soil history can determine future composition of the regenerated vegetation.

Although the rate of change that occurred during the period after the abandonment of livestock activities in the study areas was not analyzed in detail. Some works such as Kitajima and Fenner [39], showed that in altered sites where the native vegetation was eliminated completely, the rate of change of the species is very high, while in sites slightly altered the rate of change is lower because the existing species have a rapid growth, establishing a deep root system that assures water in periods of drought, competing for space, light and nutrients with understory herbs and shrubs and are endowed with chemical and mechanical defenses to resist the pressure of the herbivores. Meanwhile Clewell and Aronson [40] and Kelm et al. [41] note that climatic factors like temperature and precipitation along with animal-plant interactions (seed disperser native fauna), are essential elements in the recovery of altered habitat. Thus, sites subjected to intense livestock are more likely to be recovered since they can create an appropriate microenvironment for regeneration and establishment of species, that those sites subjected to extensive livestock where the native species have been completely eliminated, affecting in this way the succession and local regeneration of vegetation.

\section{Conclusions}

1) Post livestock regenerated communities have a high richness of species as well as high alfa diversity values, 2) evaluated communities had a mean similarity of $(48 \%), 3$ ) that even after 25 years of regenerations the most dominant species was Cenchrus ciliaris that is commonly used for cattle forage.

\section{Additional file}

Additional file 1: Floristic inventory of the study areas at the tamaulipan thornscrub vegetation. (DOCX $22 \mathrm{~kb}$ )

\section{Abbreviations}

A: Abundance; Ab: Basal area; AR: Relative abundance; D: Dominance; DR: Relative dominance; F: Frequency; FR: Relative frequency; IVI: Importance value index; N: Total number of individuals; S: Number of species; S: Surface

\section{Acknowledgements}

We thank the company TERNIUM, Mexico for all the facilities that were granted for the establishment of this research.

Funding

RENAC S.A. de C.V. supported for the logistical of the project and field activities.

\section{Authors' contributions}

MAP-L: Fieldwork, Framing experimental design. EAR-C: Data analysis and interpretation. VMM-G: Fieldwork, Data analysis. AM-O: Identification of specimens. AGA-R: Fieldwork. JGM-A Manuscript preparation. FG-O: Manuscript translation. All authors read and approved the final manuscript.

Ethics approval and consent to participate

Not applicable.

\section{Competing interests}

The authors declare that they have no competing interests.

\section{Publisher's Note}

Springer Nature remains neutral with regard to jurisdictional claims in published maps and institutional affiliations.

\section{Author details}

${ }^{1}$ Escuela Técnica Superior de Ingenieros en Montes, Universidad Politécnica de Madrid, Madrid, Spain. ${ }^{2}$ Facultad de Ciencias Forestales, Universidad Autónoma de Nuevo León, Carretera Linares-Cd. Victoria Km 145. Apartado Postal 41, 67700 Linares, N. L, Mexico. ${ }^{3}$ RENAC, S.A. de C.V, Corregidora 102 Norte, Col. Centro, 67700 Linares, NL, Mexico. ${ }^{4}$ Instituto de Ecología Aplicada, Universidad Autónoma de Tamaulipas, División del Golfo 356, 87019 Ciudad Victoria, Tamaulipas, Mexico. ${ }^{5}$ TERNIUM México, Carretera Pesquería-Ramones $\mathrm{Km}$ 15, Pesquería, NL, Mexico.

Received: 4 December 2017 Accepted: 6 April 2018

Published online: 14 April 2018

\section{References}

1. Fresco LO. Ciencia y la revolución pecuaria. Revista Enfoques FAO. 2005. http://www.fao.org/ag/esp/revista/0511sp1.htm. Accesed 11 Apr 2018.

2. SAGARPA. Nuevo León: Agenda de Innovación Agroindustrial. México: Secretaría de Agricultura, Ganadería, Desarrollo Rural, Pesca y Alimentación; 2011.

3. Arriaga L. Implicaciones del cambio de uso de suelo en la biodiversidad de los matorrales xerófilos: un enfoque multiescalar. Inv Amb. 2009;1 (1):6-16.

4. Robinson TP, Thornton PK, Franceschini G, Kruska RL, Chiozza F, Notenbaert A, Cecchi G, Herrero M, Epprecht M, Fritz S, You L, Conchedda G, See L. Global livestock production systems. Rome: Food and Agriculture Organization of the United Nations - International Livestock Research Institute; 2011.

5. García J, Jurado E. Caracterización del matorral con condiciones prístinas en Linares N. L., México. Ra Ximhai. 2008;4(1):1-21.

6. Pequeño-Ledezma MA, Alanís-Rodríguez E, Jiménez-Perez J, AguirreCalderón OA, González-Tagle MA, Molina-Guerra VM. Análisis estructural de dos áreas del matorral espinoso tamaulipeco del noreste de México. Mad Bosq. 2017;23(1):121-32.

7. Rzedowski J. Vegetación de México. 1st dig ed. México: Comisión Nacional. para el Conocimiento y Uso de la Biodiversidad; 2006.

8. Alanís E, Jiménez J, González MA, Yerana Jl, Cuellar LG, Mora-Olivo A. Análisis de la vegetación secundaria del matorral espinoso tamaulipeco, México. Phyton-Int J Exp Bot. 2013;82:185-91.

9. Foroughbakhch R, Alvarado-Vázquez MA, Carrillo-Parra A, Hernández-Piñero JL, Guzmán MA. Floristic diversity of a shrubland in northeastern Mexico. Phyton-Int J Exp Bot. 2013:82:175-84.

10. Gómez E, Díaz H, Saldívar A, Briones F, Vargas V, Grant WE. Patrón de crecimiento de pasto buffel (Pennisetum ciliare L. (Link.) Sin. Cenchrus ciliaris L.) en Tamaulipas, México. Rev Mex Cien Pec. 2007;45(1):1-17.

11. Pequeño-Ledezma MA, Alanís-Rodríquez E, Jiménez-Pérez J, González-Tagle MA, Yerena-Yamallel Jl, Cuellar-Rodríguez LG, Mora-Olivo A. Análisis de la restauración pasiva post-pecuaria en el matorral espinoso tamaulipeco del noreste de México. Cien UAT. 2012;24(2):48-53.

12. Jiménez J, Alanís E, González MA, Aguirre OA, Treviño EJ. Characterizing woody species regeneration in areas with different land history tenure in the Tamaulipan thornscrub, Mexico. Southwest Nat. 2013;58(3):299-304.

13. Alanís E, Jiménez J, Canizales PA, González H, Mora-Olivo A. Estado actual del conocimiento de la estructura arbórea y arbustiva del matorral espinoso tamaulipeco del noreste de México. Rev Iberoam Cienc. 2015;2(7):69-80.

14. Mora CA, Jiménez J, Alanís E, Rubio EA, Yerena Jl, González MA. Efecto de la ganadería en la composición y diversidad arbórea y arbustiva del matorral espinoso tamaulipeco. Rev Mex Cien Forest. 2013;17(4):124-37. 
15. Díaz E, Hernández J, Flores P, Elizondo E, Alanís E, Jiménez J. Regeneración y restauración del matorral espinoso tamaulipeco en el noreste de México: Estado actual del conocimiento. Rev Iberoam Cien. 2017;4(2):30-7.

16. García E. Climas (clasificación de Köppen, modificado por García). Escala, 1(1), 000. México: Comisión Nacional para el Conocimiento y Uso de la Biodiversidad; 1988.

17. Alanís E, Jiménez J, Aguirre OA, Treviño JE, Jurado E, González MA. Efecto del uso del suelo en la fitodiversidad del matorral espinoso tamaulipeco. Cien UANL. 2008;11:56-62.

18. Müeller-Dombois D, Ellenberg $\mathrm{H}$. Aims and methods of vegetation ecology. Nueva York: John Wiley and Sons; 1974.

19. Whittaker RH. Evolution and measurement of species diversity. Taxon. 1972; 21:213-51.

20. Moreno CE. Métodos para medir la biodiversidad, vol. 1. Zaragoza: M\&TManuales y Tesis SEA; 2001

21. Margalef R. Information theory in ecology. Gen Syst. 1958;3:36-71.

22. Shannon C. The mathematical theory of communication. In: Sahnnon CE, Weaver W, editors. The mathematical theory of communication. Chicago: University of Illinois Press; 1948. p. 134-54.

23. Magurran AE. Ecological diversity and its measurement. New Jersey: Princeton University Press; 1988.

24. Herrera-Arreola G, Herrera Y, Reyes-Reyes BG, Dendooven L. Mesquite (Prosopis juliflora (Sw.) DC.), huizache (Acacia farnesiana (L.) Willd.) and catclaw (Mimosa biuncifera Benth.) and their effect on dynamics of carbon and nitrogen in soils of the semi-arid highlands of Durango Mexico. J Arid Environ. 2007:69:583-98.

25. Pirhofer-Walzl K, Rasmussen J, Høgh-Jensen H, Eriksen J, Søegaard K Rasmussen J. Nitrogen transfer from forage legumes to nine neighbouring plants in a multi-species grassland. Plant Soil. 2012;350:71-84.

26. Mcgrath DA, Smith CK, Gholz HL, Oliveira FDA. Effects of land-use change on soil nutrient dynamics in Amazônia. Ecosystems. 2001;4:625-45.

27. Estrada E, Yen C, Delgado A, Villarreal J. Leguminosas del centro del estado de Nuevo León, México. An Inst Biol, UNAM Ser Bot. 2004;75:78-85.

28. Jiménez-Pérez J, Alanís-Rodríguez E, Aguirre-Calderón OA, Pando-Moreno M, González-Tagle M. Análisis sobre el efecto del uso del suelo en la diversidad estructural del matorral espinoso tamaulipeco. Mad Bosq. 2009;15(3):5-20.

29. González H, Cantú I, Ramírez RG, Gómez MV, Pando M, López JM. Potencial hídrico xilemático en cuatro especies arbustivas nativas del noreste de México. Rev Chapingo Ser C Forest Amb. 2011;17:97-109.

30. Domínguez GT, González H, Ramírez R, Estrada E, Cantú I, Gómez M, Villarreal J, Alvarado S, Alanís G. Diversidad estructural del matorral espinoso tamaulipeco durante las épocas seca y húmeda. Rev Chapingo Ser C Forest Amb. 2013:4(17):106-22.

31. Palacios RA. Los mezquites mexicanos: Biodiversidad y distribución geográfica. Bol Soc Argent Bot. 2006:41(1-2):99-121.

32. Linder HP, Lehmann CE, Archibald S, Osborne CP, Richardson DM. Global grass (Poaceae) success underpinned by traits facilitating colonization, persistence and habitat transformation. Biol Rev. 2018;93(2):1125-44.

33. Sharif-Zadeh F, Murdoch AJ. The effects of temperature and moisture on after-ripening of Cenchrus ciliaris seeds. J Arid Environ. 2001;49(4):823-31.

34. Marshall VM, Lewis MM, Ostendorf B. Buffel grass (Cenchrus ciliaris) as an invader and threat to biodiversity in arid environments: a review. J Arid Environ. 2012;78:1-12.

35. Jiménez J, Alanís E, Ruiz J, González M, Yerena J, Alanís G. Diversidad de la regeneración leñosa del matorral espinoso tamaulipeco con historial agrícola en el noreste de México. Ciencia UANL. 2012;15(58):66-71.

36. Mora-Donjuán CA, Rubio-Camacho EA, Alanís-Rodríguez E, Jiménez-Pérez J, González-Tagle MA, Mata-Balderas JM, Mora-Olivo A. Composición y diversidad vegetal de un área de matorral desértico micrófilo con historial pecuario en el Noreste de México. Polibotanica. 2014;38:53-66.

37. Molina-Guerra VM, Pando-Moreno M, Alanís-Rodríguez E, CanizalesVelázquez PA, González-Rodríguez H, Jiménez-Pérez J. Composición y diversidad vegetal de dos sistemas de pastoreo en el matorral espinoso tamaulipeco del Noreste de México. Rev Mex Cien Pec. 2013;4(2):361-71.

38. Canizales PA, Alanís E, Aranda R, Mata JM, Jiménez J, Alanís G, Uvalle Jl, Ruíz MG. Caracterización estructural del matorral submontano de la Sierra Madre Oriental, Nuevo León. Rev Chapingo Ser C Forest Amb. 2009;15(2):115-20.

39. Kitajima K, Fenner M. Ecology of seedling regeneration. In: Fenner M, editor. Seeds: the ecology of regeneration in plant communities (2nd ed). Londres: CAB Publishing; 2000. p. 331-59.
40. Clewell AF, Aronson J. Ecological restoration: principles, values, and structure of an emerging profession. Washington, DC: Island Press; 2017.

41. Kelm DH, Wiesner KR, Von Helversen O. Effects of artificial roosts for frugivorous bats on seed dispersal in a Neotropical forest pasture mosaic. Conserv Biol. 2007;22(3):733-41.

\section{Ready to submit your research? Choose BMC and benefit from:}

- fast, convenient online submission

- thorough peer review by experienced researchers in your field

- rapid publication on acceptance

- support for research data, including large and complex data types

- gold Open Access which fosters wider collaboration and increased citations

- maximum visibility for your research: over $100 \mathrm{M}$ website views per year

At BMC, research is always in progress.

Learn more biomedcentral.com/submissions 